\title{
Equine Anatomedia: Development, Integration and Evaluation of an E-Learning Resource in Applied Veterinary Anatomy
}

\author{
Anatomedia Equina: Desarrollo, Integración y Evaluación de un Recurso E-Learning en Anatomía \\ Veterinaria Aplicada
}

Ashraf A. El Sharaby*; Mohamed A. M. Alsafy** \& Samir A.A. El-Gendy**

EL SHARABY, A. A.; ALSAFY, M. A. M. \& EL-GENDY, S. A. A. Equine Anatomedia: Development, integration and evaluation of an e-learning resource in applied veterinary anatomy. Int. J. Morphol., 33(4):1577-1584, 2015.

SUMMARY: In Egypt, there is a growing movement to encourage veterinary student-centered learning using the most up to date educational technologies. This paper focuses on a computer-facilitated learning program "Equine Anatomedia", which comprises now two modules (head and digit) fully integrated with the applied anatomy curriculum at Alexandria and Damanhour Universities. The educational design of this program allows students and clinicians to explore anatomical concepts, principles and procedure guidelines in a manner more suited to their individual learning needs than traditional methods. The program comprises over 300 high quality images and diagrams, audio and video clips as well as animated graphics with colored keys highlighting the anatomical features. Staff and student feedback indicates that Equine Anatomedia is an effective and engaging learning tool which helps students to develop their knowledge in anatomy and to appreciate its relevance in clinical situations. In addition, it encourages student-staff interaction and is a useful tool in overcoming the challenges of limited resources and increasing numbers of students.

KEY WORDS: Anatomedia; Applied veterinary anatomy; Equine.

\section{INTRODUCTION}

In Egypt, the veterinary curriculum adopted for undergraduates is composed of a 5-year traditional discipline-based approach with clear demarcation between the basic sciences (e.g. anatomy, biochemistry, physiology, microbiology) and the clinical sciences. Students cover the basic sciences in the first three years of their studies before applying their knowledge in the final two clinical years. At our universities, general and comparative anatomy is studied during the first two years and an additional independent course of applied anatomy is studied in the fourth year. Students have reported that they are not faced with situations labeled anatomy; instead, they are faced with cases of illnesses. They also complain about the relative lack of resources while they are learning in the first and second years. Despite this, students pay great attention and enthusiasm for the applied anatomy course, which we offer in the fourth year. They praise the need for the given topics and for more integration with the relevant clinical courses (Abutarbush et al., 2006).
Individual differences in approaches to learning, prior knowledge and levels of interest lead students to approach an anatomical problem in a variety of ways, which support higher levels of cognition, including reflective thinking (Croy \& Dobson, 2003; Dev et al., 2002; Josephson \& Moore, 2006; Khalil et al., 2005a; Laurillard, 2013; Linton et al., 2005; Perry et al., 2007; Ramsden, 2003). Evaluation studies have also demonstrated the potential of e-learning for the enhancement of students' professional skills (Abutarbush et al.; Khalil et al., 2005a; Wilkes \& Bligh, 1999). Although the implementation of multimedia in addition, online courses have encouraged in Egypt more than 15 years, the validity of using these resources for education has not been evaluated. In this manuscript, we focus on "Equine Anatomedia", our-learning resource we started recently to use in the curriculum to provide a more individualized learning experience. We surveyed students and discussed the validity of using it as an educational tool with the previous and relevant attempts.

\footnotetext{
* Department of Anatomy and Embryology, Faculty of Veterinary Medicine, Damanhour University, Damanhour, Egypt.

${ }^{* *}$ Department of Anatomy and Embryology, Faculty of Veterinary Medicine, Alexandria University, Edfina, Egypt.
} 


\section{MATERIAL AND METHOD}

Development of Equine Anatomedia. Equine Anatomedia is an innovative application whose ongoing development began seven years ago and is designated to include several modules, two of which (head and digit) have been completed and are currently integrated in the applied anatomy course (Fig. 1). We are working to include the neck, thorax, abdomen and the pelvis as well as the limbs. Equine Anatomedia contains now over 300 high quality images and diagrams, audio and video clips as well as animated graphics with colored keys highlighting the anatomical details. During the development phase, precisely during the initial user testing, we found out that narrated text and labels of only the most critical structures are required for students. Therefore, we insert several audio and animated clips similar to the relevant attempts of (Brenton et al., 2007; Eizenberg et al., 2013; Josephson \& Moore; Lip et al., 2000). Students confirmed that the eventual format of Equine
Anatomedia enable them to move easily between the morphology of individual structure and its topographic approaches as well. However, students inquired also for the need to add a specific clinical focus related to each anatomical structure whenever it is available. Therefore, we embedded the most clinically based questions within the program, presenting the key anatomical concepts and principle guidelines. In Equine Anatomedia, students can easily gain access to the characteristic features including muscle grooves, boney prominences, subcutaneous structures, joints and the cutaneous innervation as well as the sites of local anesthesia and joint injection. Once the student begins exploring a particular content area, by selecting it from the left side menu, they can easily explore more details by moving between the perspective keys (text, image, audio narrations, video clips and interactive graphics) in the bottom of each page (Figs. 2 and 3).

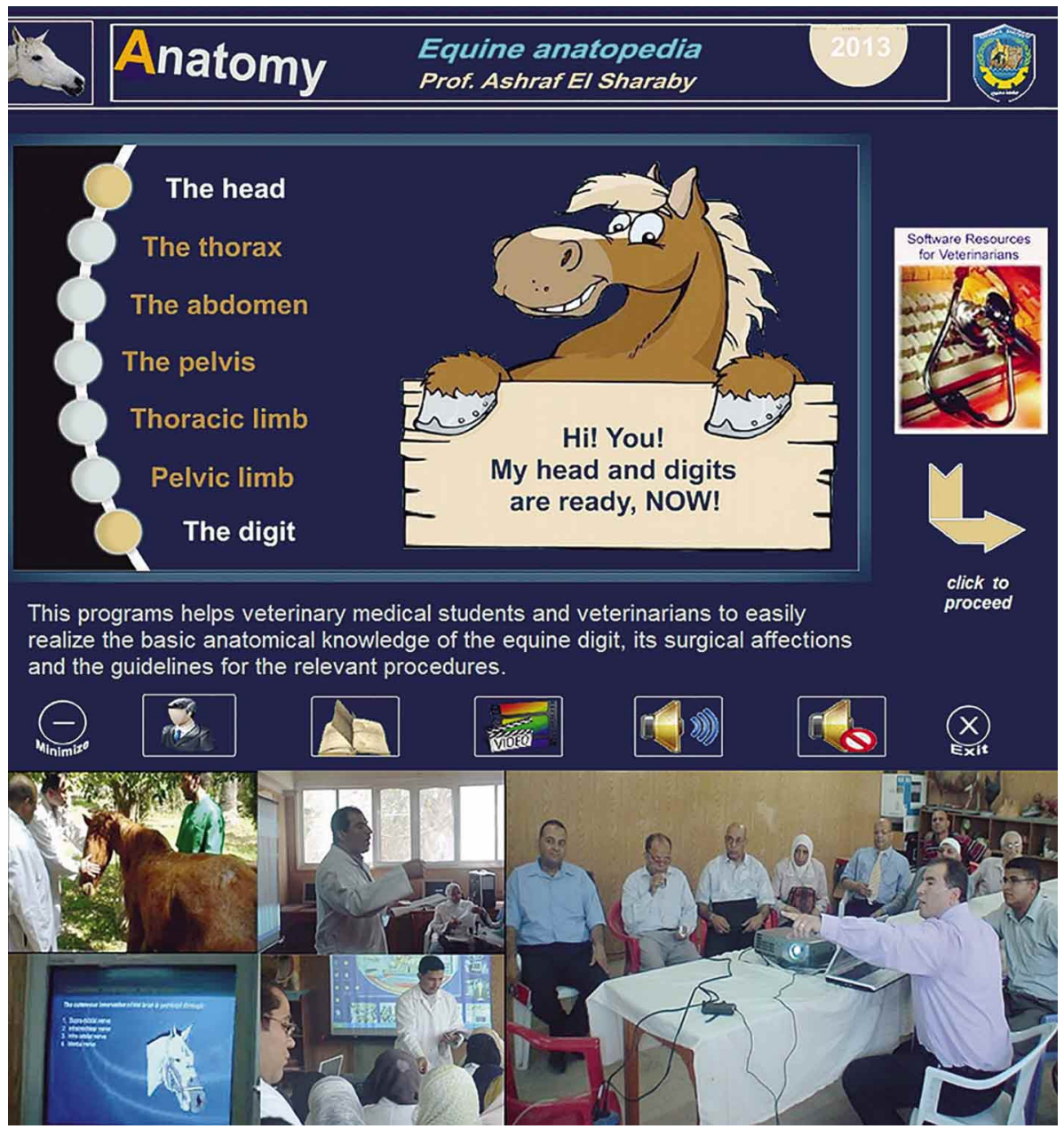

Fig. 1. Photos showing the program's table of contents, and its integration as well as the evaluation processing during meeting with experts. 


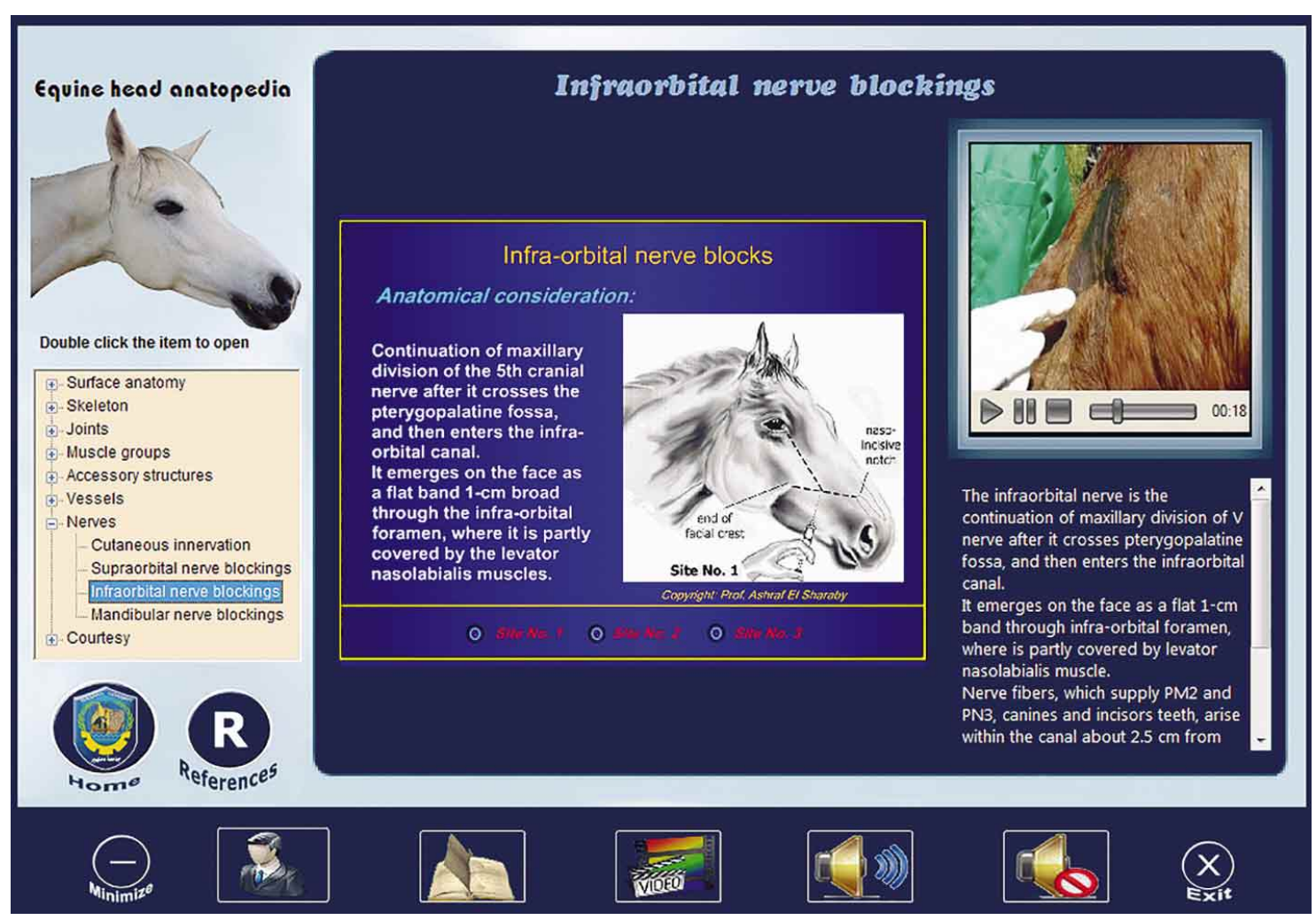

Fig. 2. Screenshots of the program "the head showing titles of the topics" side menu "left", the main window that includes the animation (left), video (top right), text (top bottom), and the bar of the function keys in the bottom of the screen.

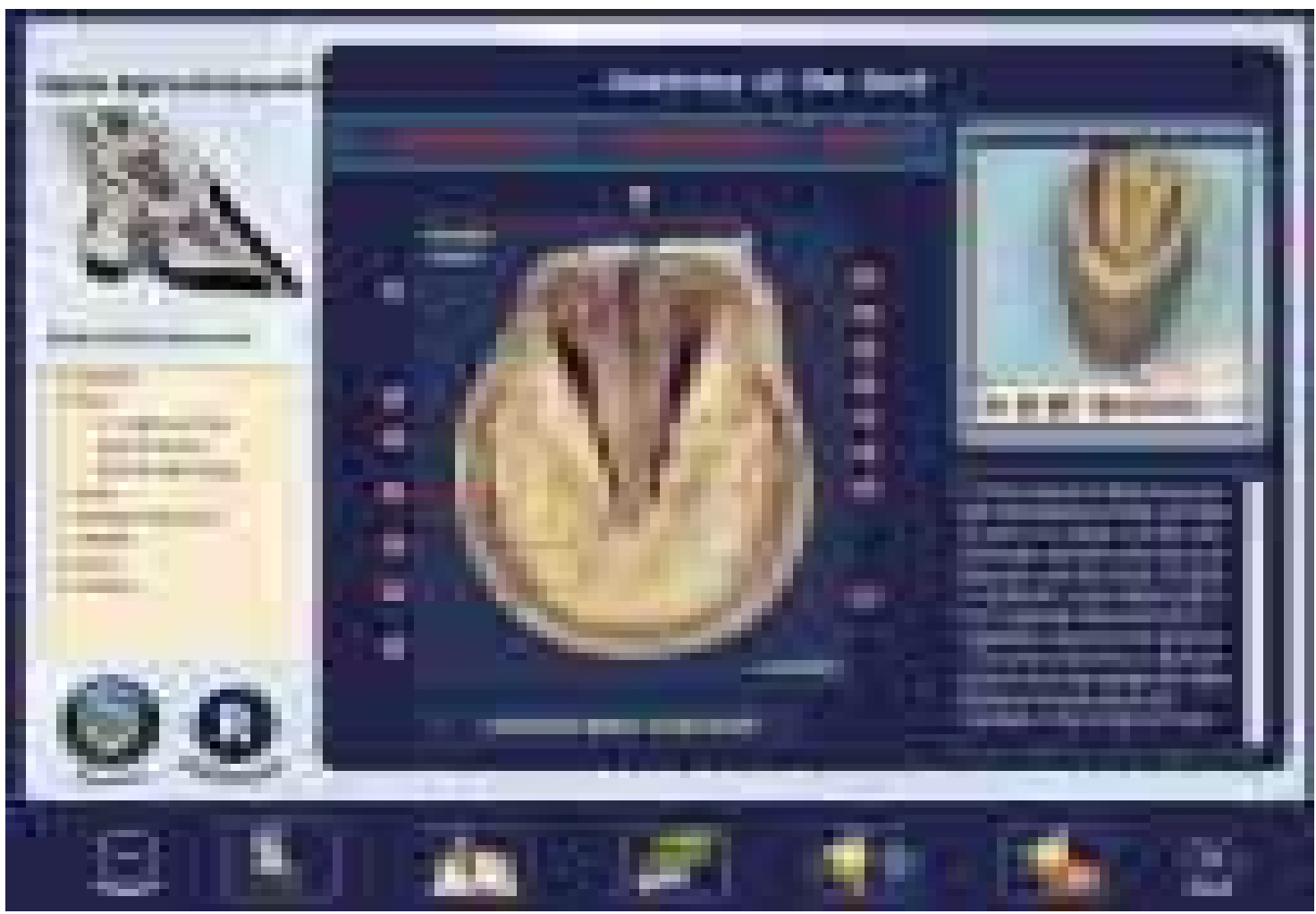

Fig. 3. Screenshots of the program "the digit showing titles of the topics" side menu "left", the main window that includes the animation (left), video (top right), text (top bottom), and the bar of the function keys in the bottom of the screen. 
Integrating Equine Anatomedia into the curriculum. Equine Anatomedia has been integrated in the course in two ways: as an explanatory tool in the lectures; and as a preparatory and revision tool in the anatomy practical. By using it as a lecturing tool, instructors can greatly enhance the understanding of students of the anatomical concepts and principles. Instructors are also able to familiarize students with the navigation of the program while also investigating the anatomical structures. Using the program as a preparatory tool in their practical, the students first can identify and review the anatomical structures related to the region through the dissection images and diagrams and also the media clips. Second, students can use the program as a useful tool to discuss the applied anatomical guidelines or procedures, and how to reinforce the main principles and relate them to the live animal. The important characteristic of Equine Anatomedia is that while being detailed and complex it is also flexible, encouraging more effective learning. Parallel to the use of this tool as a complement to the learning environment, we provided students with a variety of more traditional resources such as textbooks, notes atlases and web pages containing high quality images and animations.

Evaluating student and staff perceptions of Equine Anatomedia: Equine Anatomedia has been extensively evaluated, and some early quantitative results about the perception of students during the development process and initial user phase have been previously reported (El Sharaby \& Abdel Wahid, 2007). In this evaluation, we surveyed students using a pre-/ post-test comparison group design and a fivepoint Likert scale (i.e. Strongly Disagree $=1$, Disagree $=2$, Neutral $=3$, Agree $=4$ and Strongly Agree $=5$ ). In addition, we conducted a qualitative evaluation using a group interview with 20 students who volunteered to participate in the evaluation process. These students were asked for suggestions on how to improve this nascent e-learning tool. We found out that the student responses to the questionnaires inconsistent with their oral feedback during the interviews, which was due to their inability to critically distinguish the differences between the five points of the Likert scale. Therefore, we decided to adopt the three-point scale (where 1 indicated "disagree" and 3 indicated "agree") so as to enable students to give more reliable feedback for their exact tasting of the questionnaires. In the present study, we evaluated Equine Anatomedia after its implementation in the curriculum of applied anatomy. We surveyed students $(n=330)$ using an evaluation sheet including quantitative and qualitative questionnaires. Students were inquired for the program educational design and content (Q1-Q10) and their overall perception for the program (Q11-Q20). On the other hand, the participants were given also a space to submit their views about the benefits and limitations of this tool and their suggestions for its improvement. We surveyed also staff ( $\mathrm{n}=$
20) using the same evaluation sheet after presenting the program in an independent session. The percentages of these responses were calculated, analyzed and presented in Table I. Selection of participant students and ethical considerations:Veterinary students $(n=330)$ who had completed the majority of theoretical and practical courses of anatomy were invited to voluntarily participate in this study. To provide students with necessary information regarding their participation, we invited them for a briefing session. They were assured that evaluation was confidential; all data were kept anonymous and was not related to their formal course assessment. Since this study necessitated that students have the ability to use a computer (Sun et al., 2008), we selected only competent students having adequate acquaintances on basic IT requirements and the application interface. The study was reviewed and approved by the faculty Ethics, research and educational committee.

\section{RESULTS}

Table I revealed student's perception of the educational design and content (Q1-Q10) as well as overall perception (Q11-Q20) of Equine Anatomedia. Generally, we found that the students were very positive about the program. The most appealing aspect of the program was the high percent of the students wanted to viewing and owns a copy, staff recorded that it is necessary for teaching and/ or learning of the applied anatomy.

The student's response to e-learning using Anatomedia, more than half $(80 \%)$ of the students found the program useful in the lectures and tutorials, more than (83.3\%) of the students preferred to use the program as a part of their practical, and (84.6\%) wanted a hybrid copy of the program for their own for the offline use. In terms of the time needed for learning the subject, $81.5 \%$ of surveyed students and staff confirmed that using the traditional method of learning was time consuming meanwhile using the program was comparatively not. We realized that the use of animations, video clips and audio narrations were particularly effective as it was hard for the student to study from text and pictures alone but $87.3 \%$ of students recognized that the audio clips was easy to follow and $79.7 \%$ confirmed that the images, animations and text were illustrative, valuable and helps understand applied anatomy topics. Numerous students requested access to other parts of the body in a similar style.

All the surveyed staff agreed on the great validity of Equine Anatomedia to supplement traditional lecturing, and agreed to contribute by adding more modules. They also added that the tool gives students exposure to the clinical 
Table I. Percentages of student's perception of the educational design and content (Q1-Q10) as well as overall perception of Equine Anatopedia (Q11-Q20). Student number= 330 and staff number= 20.

\begin{tabular}{clccc}
\hline Q & Quantitative questionnaires & Disagree & Neutral & Agree \\
\hline 1 & Visually attractive? & $4.5 \%$ & $7.6 \%$ & $87.9 \%$ \\
2 & A user-friendly application & $1.2 \%$ & $15.8 \%$ & $83.0 \%$ \\
3 & F acilitates navigation of the contents & $6.1 \%$ & $16.1 \%$ & $77.8 \%$ \\
4 & Images \& animations are illustrative & $7.3 \%$ & $13.9 \%$ & $78.8 \%$ \\
5 & Presented text is concise but sufficient & $5.2 \%$ & $19.0 \%$ & $75.8 \%$ \\
6 & They are constantly well-organized & $3.7 \%$ & $14.5 \%$ & $81.8 \%$ \\
7 & Subtitles are well-addressed & $5.5 \%$ & $14.2 \%$ & $80.3 \%$ \\
8 & Images \& media clips were valuable & $7.6 \%$ & $12.7 \%$ & $79.7 \%$ \\
9 & Text \& media clips complement each other & $5.2 \%$ & $13.6 \%$ & $81.2 \%$ \\
10 & Easy to follow comprehensive audio clips & $4.85 \%$ & $7.9 \%$ & $87.3 \%$ \\
11 & Helps understand applied anatomy topics & $6.0 \%$ & $17.6 \%$ & $76.4 \%$ \\
12 & Highlights required anatomical structures & $5.5 \%$ & $19.1 \%$ & $75.4 \%$ \\
13 & Links clinical and anatomical subjects & $6.4 \%$ & $23.0 \%$ & $70.6 \%$ \\
14 & Complements to available materials & $6.4 \%$ & $10.3 \%$ & $83.3 \%$ \\
15 & Necessary for teaching and/ or learning & $7.0 \%$ & $13.0 \%$ & $80.0 \%$ \\
16 & Less time consuming versus traditional learning & $6.7 \%$ & $11.8 \%$ & $81.5 \%$ \\
17 & A sole resource for teaching and learning & $69.7 \%$ & $11.2 \%$ & $19.1 \%$ \\
18 & Encourages to develop new modules & $7.5 \%$ & $17.6 \%$ & $74.9 \%$ \\
19 & Used through a constant online access & $39.7 \%$ & $23.0 \%$ & $37.3 \%$ \\
20 & Necessary to get a copy for offline use & $4.2 \%$ & $11.2 \%$ & $84.6 \%$ \\
\hline
\end{tabular}

simulations earlier in the educational process. However, we found a common belief that Equine Anatomedia should not be used as replacement for the dissection of cadavers. But they agreed on that the Anatomedia cover share the main aim of all to promote the optimum knowledge of the clinical anatomy.

\section{DISCUSSION}

Our Anatomedia program designed and developed an educational high quality multimedia that all resources of data needed to the applied anatomy education will be available from one web page and it has the ability to access the content remotely for review within a flexible temporal framework (Brenton et al.; Eizenberg et al.; Jastrow \& Vollrath, 2003; Khalil et al., 2005 b; Lip et al.).The major critique of the published comparative studies has been that the tutorial material was often different, thereby confounding any mean-ingful comparison (Amesse et al., 2008; Khalil et al., 2005a). In this study, we maintained a high degree of content fidelity to minimize such confounders. We chose an area of study, the applied anatomy that represented the first formal exposure of the subject to the students and had relevance to their training before other clinical teaching like surgery, obstetric, internal medicine, etc.

Three-dimensional (3D) information plays an important part in the medical and veterinary education.
Appreciating complex 3D spatial relationships requires a strong foundational understanding of anatomy and mental 3D visualization skills (Preece et al., 2013). The interactive animation and virtual solids are promising tools for training spatial thinking and study achievements in undergraduate students (Cohen \& Hegarty, 2014; Siegle \& Foster, 2001).

Anatomy teaching is undergoing significant changes due to time constraints, limited availability of cadavers and technological developments in the areas of three-dimensional modeling and computer-assisted learning (Brenton et al.). Anatomy has been taught through dissection of the cadaver and study of illustrated atlases since the sixteenth century. There are no labels in the cadaver. Dissection is a destructive process and errors cannot be corrected. In addition, students study from previously prepared dissected specimens. Continuous attempts takes attention of the anatomists for many years to facilitate the students and instructors handling and studying the practical anatomy. Preservations of flexible models of hollow organs and many dried anatomical specimens were prepared (Arnautovic et al., 2005; McKiernan \& Kneller, 1983; Updike \& Holladay, 1986). Many studies to learning sectional anatomy by computed tomography (CT), magnetic resonance imaging (MRI), contrast radiography, ultrasonography and cadaver sectional anatomy (Alsafy et al., 2013, 2014; Alsafy, 2008; Desbrosse et al., 2008; Garland et al., 2002; Morgan et al., 2006; Puchalski, 2012). It was hypothesized that the newly 
developed physical model would be more effective for students to learn magnetic resonance imaging (MRI) anatomy of the foot than textbooks or computer-based 3D models (Preece et al.). A thorough knowledge of the sectional anatomy of equine limb structures and their interrelationships is crucial for accurate interpretation of diagnostic images (Denoix, 2000; Peterson \& Bowman, 1988). Nevertheless, unfortunately, body slices prepared by traditional methods are often unpleasant to handle and prone to deterioration. Residency programs are demanding an increased understanding of cross-sectional anatomy from entering students. Students agreed that dissection deepened their understanding of anatomical structures, provided anatomy textbooks were perceived as an excellent resource for learning anatomy. Interestingly, innovations used in teaching anatomy, such as interactive multimedia resources are increased (Azer \& Eizenberg, 2007; Jastrow \& Vollrath). In response to a decrease in the curriculum hours being devoted to the study of anatomy and an increase in self-directed, computer-based learning, a Web-based cross-sectional learning tool (3D-X) was developed that can improve students' ability to identify anatomical structures in CT images (Dorosh et al., 2013). The interactive animation training of the two-dimensional cross section of a virtual three-dimensional geometric figure to students increased the efficacy of the undergraduate spatial thinking (Cohen \& Hegarty). Plastination of many body parts especially the equine distal limb is a useful technique but the polymers of plastination can be used at room temperature but must be stored in a freezer and the new polymers are highly expensive (Latorre et al., 2001). New technique of learning sectional anatomy using clay models by making clay models, cutting them and comparing cut surfaces to CT and MR images (Oh et al., 2009). Bishop et al. (2010) described the development of a highly detailed finite-element computational model of rabbit ventricles constructed from high-resolution MR data.

The appearance of high-quality three-dimensional models, animations, and volumetric data are significantly appealing both to students and to health care professionals. The virtual cadaver presented through a variety of media was the new method to promote the quantitative optimum of the anatomy knowledge. Learning anatomy and surgical procedures requires both a conceptual understanding of three-dimensional anatomy and a hands-on manipulation of tools and tissue (Dev et al.; Theodoropoulos et al., 1994). There is a remarkable growth in the interest and use of multimedia programs besides the growth in skill in developing multimedia programs. There is an ocean of content on the Internet, developed without really worrying about the quality of it (Dev et al.,).
The exponential growth of ba-sic medical knowledge and the diversity of new diagnos-tic aids require that more efficacious, all-encompassing, personal forms of learning be developed. The computer- based and web-based programs became an integral part of medical student curricula (Amesse et al.; Devitt et al., 2001).

Our study's results indicate that interactive computerbased instruction was associated with improved learning large groups of students confirmed these findings. Computers have provided us the facility to adapt the way of learning; pace varies, timing varies and so do various other habits according to one's own needs and liking. A major quality of multimedia is interaction, which the machine performs with the learners. So, while we designing our multimedia software it has to be paramount on our minds that the learner should be able to interact with the program and make it suitable to his/her requirements and liking.

A deterrent for home use was the most requests of all students and the request of other parts of the body in a similar style. Therefore, we will work to enrich the program with more resources; precisely video clips with narrations on the dissected specimens as previously detailed (Josephson \& Moore), So as to help students for offline revision elsewhere outside the lab.

\section{CONCLUSIONS}

We conclude that the use of Equine Anatomedia as a complementing tool for traditional teaching of applied anatomy is advantageous. It allows full integration of the basic and clinical training of large numbers of students outside of the conventional practice sites. Students obviously perceive it benefits their learning and is easy and engaging to use, while staff perceive that it is useful in introducing them to clinical aspects before they reach clinical years.

EL SHARABY, A. A.; ALSAFY, M. A. M. \& EL-GENDY, S. A. A. Anatomedia Equina: Desarrollo, integración y evaluación de un recurso e-learning en anatomía veterinaria aplicada. Int. J. Morphol., 33(4):1577-1584, 2015.

RESUMEN: En Egipto, hay un movimiento creciente para fomentar el aprendizaje centrado en el estudiante de veterinaria utilizando las más modernas tecnologías educativas existentes a la fecha. Este trabajo se centra en un programa de aprendizaje por computación denominado "Anatomedia de Equinos", que en la actualidad está conformado de dos módulos (cabeza y dedos) to- 
talmente integrados con el plan de estudios de la asignatura Anatomía Aplicada en las Universidades de Alejandría y Damanhour, Egipto. El diseño educativo de este programa permite a los estudiantes y los médicos clínicos explorar los conceptos anatómicos, como así también principios y directrices de procedimiento relacionados a sus necesidades individuales de aprendizaje, de una manera más adecuada que los métodos tradicionales de aprendizaje. El programa cuenta con más de 300 imágenes de alta calidad y diagramas, audios y vídeos, así como gráficos animados con identificaciones de colores que destacan las características anatómicas. La retroalimentación del personal a cargo del programa y de parte de los estudiantes indica que Anatomedia de Equinos es una herramienta de aprendizaje eficaz y atractiva que ayuda a los estudiantes a desarrollar sus conocimientos en anatomía y les permite apreciar su importancia en situaciones clínicas. Además, el programa permite fomentar la interacción alumno-personal y constituye una herramienta útil que ayuda a superar los retos que ocasionan los recursos limitados y el número creciente de estudiantes.

PALABRAS CLAVE: Anatomedia; Anatomia Aplicada de Veterinaria Equina.

\section{REFERENCES}

Abutarbush, S. M.; Naylor, J. M.; Parchoma, G.; D'Eon, M.; Petrie, L. \& Carruthers, T. Evaluation of traditional instruction versus a self-learning computer module in teaching veterinary students how to pass a nasogastric tube in the horse. J. Vet. Med. Educ., 33(3):447-54, 2006.

Alsafy, M. A. M. Computed tomography and cross-sectional anatomy of the thorax of goat. Small Rumin. Res., 79:15866, 2008.

Alsafy, M. A.; El-Gendy, S. A. \& Abumandour, M. M. Computed tomography and gross anatomical studies on the head of one-humped camel (Camelus dromedarius). Anat. Rec. (Hoboken), 297(4):630-42, 2014.

Alsafy, M. A.; El-Gendy, S. A. \& El Sharaby, A. A. Anatomic reference for computed tomography of paranasal sinuses and their communication in the Egyptian buffalo (Bubalus bubalis). Anat. Histol. Embryol., 42(3):220-31, 2013.

Amesse, L. S.; Callendar, E.; Pfaff-Amesse, T.; Duke, J. \& Herbert, W. N. Evaluation of computer-aided strategies for teaching medical students prenatal ultrasound diagnostic skills. Med. Educ. Online, 13:13, 2008.

Arnautovic, I.; Henry, R. W.; Pobric, H.; Avdic, R.; Cutahija, R.; Tabakovic, M. \& Reed, R. B. Improved method for dried anatomical specimen preparation. J. Int. Soc. Plast., 20:13$5,2005$.
Azer, S. A. \& Eizenberg, N. Do we need dissection in an integrated problem-based learning medical course? Perceptions of first- and second-year students. Surg. Radiol. Anat., 29(2):173-80, 2007.

Bishop, M. J.; Plank, G.; Burton, R. A.; Schneider, J. E.; Gavaghan, D. J.; Grau, V. \& Kohl, P. Development of an anatomically detailed MRI-derived rabbit ventricular model and assessment of its impact on simulations of electrophysiological function. Am. J. Physiol. Heart Circ. Physiol., 298(2):H699-718, 2010.

Brenton, H.; Hernandez, J.; Bello, F.; Strutton, P.; Purkayastha, S.; Firth, T. \& Darzi, A. Using multimedia and Web3D to enhance anatomy teaching. Comput. Educ., 49:32-53, 2007.

Cohen, C. A. \& Hegarty, M. Visualizing cross sections: Training spatial thinking using interactive animations and virtual objects. Learn. Individ. Differ., 33:63-71, 2014.

Croy, B. A. \& Dobson, H. Radiology as a tool for teaching veterinary anatomy. J. Vet. Med. Educ., 30(3):264-9, 2003.

Denoix, J. M. The Equine Distal Limb: An Atlas of Clinical Anatomy and Comparative Imaging. Barcelona, Manson Publishing, 2000.

Desbrosse, F. G.; Vandeweerd, J. M. E. F.; Perrin, R. A. R.; Clegg, P. D.; Launois, M. T.; Brogniez, L. \& Gehin, S. P. A technique for computed tomography (CT) of the foot in the standing horse. Equine Vet. Educ., 20(2):93-8, 2008.

Dev, P.; Montgomery, K.; Senger, S.; Heinrichs, W. L.; Srivastava, S. \& Waldron, K. Simulated medical learning environments on the Internet. J. Am. Med. Inform. Assoc., 9(5):437-47, 2002 .

Devitt, P.; Smith, J. R. \& Palmer, E. Improved student learning in ophthalmology with computer-aided instruction. Eye (Lond.), 15(Pt. 5):635-9, 2001.

Dorosh, K.; Bhattacharyya, S.; Haase, P. \& Johnson, M. Effectiveness of a Dynamic Cross-Sectional Anatomy Learning Tool (3D-X) at Improving Students' Ability to Interpret CT Images. Med. Sci. Educ., 23(3):364-76, 2013.

Eizenberg, N.; Briggs, C.; Barker, B. \& Grkovic, I. An@tomedia: A New Approach To Medical Education: Developments In Anatomy. Anatomedia Pty. Ltd., 2013. Available from: http:/ /www.anatomedia.com/

El Sharaby, A. A. \& Abdel Wahid, R. Equine head an@tomedia: A computer- based program for self-education on the applied anatomy of equine head. Alex. J. Vet. Sci., 25:123-30, 2007.

Garland, M. R.; Lawler, L. P.; Whitaker, B. R.; Walker, I. D.; Corl, F. M. \& Fishman, E. K. Modern CT applications in veterinary medicine. Radiographics, 22(1):55-62, 2002. 
Jastrow, H. \& Vollrath, L. Teaching and learning gross anatomy using modern electronic media based on the visible human project. Clin. Anat., 16(1):44-54, 2003.

Josephson, E. M. \& Moore, L. J. An electronic instructor for gross anatomy dissection. J. Vet. Med. Educ., 33(3):465-73, 2006.

Khalil, M. K.; Johnson, T. E. \& Lamar, C. H. Comparison of computer-based and paper-based imagery strategies in learning anatomy. Clin. Anat., 18(6):457-64, 2005a.

Khalil, M. K.; Lamar, C.H. \& Johnson, T. E. Using computer-based interactive imagery strategies for designing instructional anatomy programs. Clin. Anat., 18(1):68-76, 2005 b.

Latorre, R.; Vázquez, J. M.; Gil, F.; Ramirez, G.; Lopez-Albors, O.; Orenes, M.; Martinez-Gomariz, F. \& Arenciba, A. Teaching anatomy of the distal equine thoracic limb with plastinated slices. J. Int. Soc. Plast., 16:23-30, 2001.

Laurillard, D. Rethinking University Teaching: A Conversational Framework for the Effective Use of Learning Technologies. New York, RoutledgeFalmer, 2002.

Linton, A.; Schoenfeld-Tacher, R. \& Whalen, L. R. Developing and implementing an assessment method to evaluate a virtual canine anatomy program. J. Vet. Med. Educ., 32(2):249-54, 2005.

Lip, G.; O’Brien, M.; Tanner, A.; Foley C. \& Grimson, J. Teaching Anatomy Using Multimedia. TSMJ, 1:18-20, 2000.

McKiernan, B. C. \& Kneller, S. K. A simple method for the preparation of inflated air-dried Lung specimens. Vet. Radiol., 24(2):58-62, 1983.

Morgan, J. W.; Santschi, E. M.; Zekas, L. J.; Scollay-Ward, M. C.; Markel, M. D.; Radtke, C. L.; Sample, S. J.; Keuler, N. S. \& Muir, P. Comparison of radiography and computed tomography to evaluate metacarpo/metatarsophalangeal joint pathology of paired limbs of thoroughbred racehorses with severe condylar fracture. Vet. Surg., 35(7):611-7, 2006.

Oh, C. S.; Kim, J. Y. \& Choe, Y. H. Learning of cross-sectional anatomy using clay models. Anat. Sci. Educ., 2(4):156-9, 2009.

Perry, J.; Kuehn, D. \& Langlois, R. Teaching anatomy and physiology using computer-based, stereoscopic images. J. Coll. Sci. Teach., 36(4):18-23, 2007.

Peterson, P. R. \& Bowman, K. F. Computed tomographic anatomy of the distal extremity of the horse. Vet. Radiol., 29(4):147-56, 1988 .

Preece, D.; Williams, S. B.; Lam, R. \& Weller, R. "Let's get physical": advantages of a physical model over 3D computer models and textbooks in learning imaging anatomy. Anat. Sci. Educ., 6(4):216-24, 2013.
Puchalski, S. M. Advances in equine computed tomography and use of contrast media. Vet. Clin. North Am. Equine Pract., 28(3):563-81, 2012.

Ramsden, P. Learning to Teach in Higher Education. Abingdon, RoutledgeFalmer, 2003.

Siegle, D. \& Foster, T. Laptop computers and multimedia and presentation software: Their effects on student achievement in anatomy and physiology. J. Res. Technol. Educ., 34(1):29-37, 2001.

Sun, P. C.; Tsai, R. J.; Finger, G.; Chen, Y. Y. \& Yeh, D. What drives a successful e-Learning? An empirical investigation of the critical factors influencing learner satisfaction. Comput. Educ., 50(4):1183-202, 2008.

Theodoropoulos, G.; Loumos, V. \& Antonopoulos, J. A veterinary anatomy tutoring system. Comput. Methods Programs Biomed., 42(2):93-8, 1994.

Updike, S. J. \& Holladay, S. D. Preparation of flexible models of hollow gastrointestinal organs. Anat. Rec., 216(2):207-10, 1986.

Wilkes, M. \& Bligh, J. Evaluating educational interventions. BMJ, 318(7193):1269-72, 1999.

\author{
Correspondence to: \\ Mohamed Alsafy \\ Department of Anatomy and Embryology \\ Faculty of Veterinary Medicine \\ Damanhour University \\ Damanhour \\ EGYPT
}

Email: safy73@yahoo.com

Received: 09-01-2015

Accepted: 02-06-2015 